\title{
Novas tecnologias reprodutivas, velhas desigualdades?
}

\author{
Novas tecnologias reprodutivas \\ conceptivas: questões e \\ desafios.
}

GROSSI, Miriam Pillar; PORTO, Rozeli; TAMANINI, Marlene. (Orgs.).

Brasília: Letras Livres, 2003. 196 p. (Coleção Bioética, 3).

Esta é uma pergunta que talvez insista em inquietar as leitoras e os leitores que venham a se aventurar pelas páginas do livro Novas tecnologias reprodutivas conceptivas: questões e desafios. A obra é resultado das apresentações e reflexões suscitadas na Jornada Novas Tecnologias Reprodutivas Conceptivas: Questões e Desafios, realizada em 2003 pelo Núcleo de Identidades de Gênero e Subjetividades da Universidade Federal de Santa Catarina.

Os artigos indicam a formação de um novo campo de pesquisa para as Ciências Humanas, o campo das Novas Tecnologias Reprodutivas, e são produto de experiências de pesquisas desenvolvidas no âmbito de cursos de pósgraduação, que resultaram em teses já defendidas. Os estudos foram desenvolvidos sob diferentes abordagens teóricas e metodológicas, porém, as autoras parecem comungar de uma mesma perspectiva: a noção teórica de gênero que perpassa todos os textos apresentados. Quase comum, porque predominante nos textos, é a tradição de pesquisa antropológica, área de formação de boa parte das autoras. Tal fato, se por um lado insinua a escassez de outros olhares, no múltiplo leque das Ciências Humanas para esse novo campo de pesquisa, por outro traz mais 
uma importante contribuição da Antropologia para o estudo de temas do cotidiano urbano.

Vale ressaltar que o livro tem o mérito de ser uma das poucas publicações a romper a barreira de um campo que, no Brasil, até recentemente esteve restrito às pesquisas biomédicas.

O que há de muito específico no livro e que parece fugir da perplexidade e mesmo encantamento diante das novas formas de controle e criação da vida, que encontramos em muitos dos textos que discorrem sobre as Novas Tecnologias Reprodutivas, é, por exemplo, o artigo de Alexandra Rotania que aborda o poder da ciência, e mais especificamente da biotecnologia, em transformar inovações tecnológicas em necessidades vitais, criando assim novas necessidades de consumo. A autora chama a atenção para o poder que existe em toda técnica, alertando para a necessidade de regulamentação, pois qualquer técnica é produto do agir humano, passível de valoração moral, sendo sua aceitação acrítica um risco para a sociedade.

A pergunta que inicia esta resenha pode ser estimulada durante leitura do texto de Rosana Barbosa, quando discute o acesso de mulheres ricas e pobres aos serviços privados e públicos que oferecem tratamento para infertilidade. A autora demonstra que a reprodução das desigualdades sociais é evidenciada em situações como a chamada "doação compartilhada de óvulos", em que mulheres com maior poder aquisitivo pagam as drogas para estimulação ovariana para mulheres de serviços públicos. Em retribuição, estas últimas 'doam' parte de seus óvulos para aquelas que podem pagar. Situação indicativa de que as desigualdades se mantêm, ainda que com nova roupagem.

A configuração de um novo mercado de consumo é demonstrada por Martha Ramirez quando relata a existência de planos criados por algumas clínicas visando a facilitar o acesso às novas tecnologias. llustrativo do fenômeno é o material publicitário divulgado em páginas eletrônicas, como o "Plano Cegonha", que com a ajuda de instituição financeira parcela os custos do tratamento, e o chamado "Projeto Baby Bag", que facilita $o$ acesso de pessoas interessadas a São Paulo, incluindo no pacote hospedagem e passeios turísticos. Exemplo da intersecção entre tecnologia, ciência e capital.

A crítica à absolutização do desejo de ter filhos é feita por Marilena Correa, que, ao problematizar esse desejo, alerta para a ênfase no verbo ter, que pode significar a objetificação da criança, em que há o risco de ser desejada como um objeto de consumo. A pesquisadora sinaliza ainda para a perigosa correspondência entre um desejo que não tem limites com uma prática médica que raramente se indaga sobre até onde as novas tecnologias reprodutivas são válidas. Também a psicanalista Amanda Pinos indica que há de se ter reservas quanto ao discurso da medicina contemporânea, que estimula a ilusão de que tudo é possível e acena para a possibilidade de apagar qualquer sintoma que denuncie nossa incompletude.

A criação pela biomedicina do híbrido casal infértil é vista por Marlene Tamanini como uma categoria que, se por um lado desloca as dificuldades da concepção para o casal, diluindo assim a atribuição da responsabilização da mulher, por outro lado não chega a nomear o homem como infértil. A autora discute os possíveis desdobramentos da entrada do homem no cenário do processo reprodutivo medicalizado e indica a necessidade de estudos que abordem o tema paternidade.

Naara Luna aborda a publicização das inovações biotecnológicas por meio da mídia e sua apropriação pelo público leigo. A autora estuda a repercussão da novela $O$ clone, exibida pela Rede Globo de Televisão, em entrevistas realizadas com pacientes do ambulatório de reprodução humana de uma universidade pública. Rosely Costa também entrevistou usuárias e usuários de um ambulatório de hospital público em sua pesquisa, evidenciando a diversidade de posicionamentos dos entrevistados na construção de representações que os auxiliam na definição do que é considerado mais importante para a atribuição de maternidade e paternidade.

Há que se destacar o brilhante artigo de Débora Diniz sobre o aborto seletivo no Brasil, em que a autora analisa um processo que tramitou no Distrito Federal em que foi solicitada a interrupção de gestação de feto com malformação incompatível com vida. O caso evidencia $\circ$ descompasso entre 0 desenvolvimento da tecnologia e a lei sobre o aborto no Brasil. Descompasso que inúmeras vezes segue vitimizando as mulheres.

Além dos trabalhos divulgados na Jornada, - livro inclui os debates ocorridos durante o evento. Conta ainda com uma valiosa bibliografia comentada, organizada por Roseli Porto, fundamental para quem se inicia no campo das 
Novas Tecnologias Reprodutivas. Textos que tornam o livro necessário não apenas para as pesquisadoras do campo das Novas Tecnologias Reprodutivas, como também importante leitura para quem quer ter informações consistentes, que ofereçam subsídios para posicionamentos sobre o tema.

Cláudia Medeiros de Castro Universidade Camilo Castelo Branco 